\title{
Is Bottled Water Commodity in Saudi Arabia?
}

\author{
Abdullah M. Alhidari ${ }^{1} \&$ Soad Abdullah Almeshal ${ }^{1}$ \\ ${ }^{1}$ Marketing Department, King Saud University, Riyadh, Saudi Arabia \\ Correspondence: Abdullah M. Alhidari, Marketing Department, King Saud University, Riyadh, Saudi Arabia.
}

Received: February 22, 2018

Accepted: March 19, 2018 Online Published: May 7, 2018

doi:10.5539/ijms.v10n2p86

URL: https://doi.org/10.5539/ijms.v10n2p86

\begin{abstract}
The current study addresses an important question: is bottled water a commodity? How consumers in Saudi Arabia categorize bottled water? This study provides insights for marketers to understand the transition between commodity and brand. It also adds to the current literature on price fairness and brand trust by highlighting the impact of product design and e-WOM. Also, brand trust may not act as trigger to purchase intention, but it helps consumers to have higher value of the product. A total of 1079 completed and usable responses were from the total participants. The relationships between the constructs were tested using Structural Equation Modeling (SEM) with Maximum Likelihood (ML) estimate. Next, the theoretical and managerial implications to the results of the study are discussed. This study broadens our understanding of the product transformation from commodity to brand. Moreover, the result helps managers to differentiate the products and enhance brand trust for consumers to positively perceive the product price. The current study adds to the literature by addressing the consumers' understanding of branding and commodity. Additionally, empirical evidence through this study contributes to the practitioners in the Saudi food market.
\end{abstract}

Keywords: product design, e-WOM, brand trust, price fairness, commodity, bottled water

\section{Introduction}

"There is no such thing as a commodity. All goods and services are differentiable" (Levet, 1980, p. 83). Changes in lifestyle, preferences, and health care lead to several changes in the hierarchy of the products and its classifications. Accordingly, the increase in bottled water consumption and the people perception of bottled water as a safe source of water in many countries, even the ones that have clean tap water (Ferrier, 2001). Bottled water is the most consumed beverages in the U.S. with 39.3 per capita in 2016 (compare to 38.5 per capita for soft drinks) (Fortune, 2017). In 2016, Saudies drank 5.1 billion liters of bottled water (Passport, 2017).

Is bottled water a commodity or a brand? To answer this question, different issues need to be discussed. First, the shift of the usage of bottled water is due to several causes such as; the taste of tap water, health purposes, and the availability of bottled water. Second, bottled water industry is growing rapidly in the recent years as healthy supernumerary to tap water and soda drinks (Doria, 2006). More than that, the bottled water market is success to attract consumers to consume bottled water (Feliciano, 2014). In addition, the cost of bottled water advertisements is less than any other brand/product in the beverage industry (International Bottled Water Association, 2014).

From a production cost, bottled water is more expensive than tap water, if we compare delivery in both situations, tap water is fixed in predetermined places where bottled water can be available at different places and can be carried anywhere.

Accordingly, several factors have pointed out the fact that bottled water is transfered from being commodity to being a brand category in consumers' minds. The product might be a commodity in one area of the world and a brand in another area of the world, as Achenbaum (1993) noted that consumer's perception is what distinguishes a brand from unbranded commodity. Thus, a brand is in the consumer's mind.

Thus, the current study investigates an argument regarding the positioning of bottled water in the consumers' minds. Furthermore, this study illustrates the influence of certain variables namely, product design, e-WOM, brand trust and price fairness to figure out the real placement of bottled water in Saudi Arabia context. In the next sections the problem of the study will be stated, literature review will be provided then the empirical analysis with results and discussion and future trends will be discussed. 


\subsection{Problem Statement}

The current study seeks to investigate an important issue in Saudi Arabia markets, which is, do Saudi consumers perceive bottled water as a commodity or as a brand. The argument of whether bottled water is commodity had spark debate between scholars (e.g., Jaffee \& Newman, 2013; Laxer \& Soron, 2006). This argument need to be proved to understand the consumers' preference and classification to this product which may change the bottled water category to be brand or stay treated as a commodity.

\subsection{Importance of the Study}

According to the tremendous changes in Saudi society, consumers` preferences and their list of needs and wants has been changed in the last ten years. Therefore, this study will shed lights on the meaning of commodities in Saudi consumers. The study will illustrate the effect of product design, brand trust, e-WOM and price fairness that consumers accept to bottled water. More than that, the study figures out the influence of trust on the price fairness as a mediating variable between product design and price fairness. Finally, the study will contribute to the literature regarding the consumers' behavior about how they perceive product as commodities or brands.

\section{Literature Review}

\subsection{Theoretical Background}

It is important to understand the classification of the products to commodities or brands in the market and from the consumers' perspective. Previous studies explained branding theory where the products should be consistent to be brands (Park et al., 1991). Consistent means reduce the uncertainty, the high quality and the differentiation to ensure the confidence of the purchase result (Alderson, 1957). More than that, a brand is distinguished from a commodity counterpart through the consumer's trust (Achenbaum, 1993). Branding is a type of differentiation because it competes with features, price, and value added (Franzen, 1999). Aaker (1991) defined brand as a name and/or symbol intended to identify the product and differentiate it from competitors. Commoditization is the high match between competitors' products in the same category in regard to features, prices, shape, color and trust, etc. (Dumlupinar, 2006). On the other hand, differentiation is the level of the added-value of each product. In both situation price is an essential factor in the classification to commoditization or branding. Price is the best measure of brand value which is associates with customer satisfaction (Johnson et al., 2001; Lange et al., 1998).

\subsection{Product Design}

Recently, product design becomes an important element to differentiate the product from competition. Products that have the same design might be categorized as commodity. Product design is important to introduce not only the external shape of the product but also consumer evaluates the product higher or lower based on product design. Also, product design is essential when changing product positioning and product image (Brunner et al., 2016). Traditionally, the design of a product was less important than other factors in the production system (Azzi et al., 2012; Simms \& Trott, 2014). Moreover, the importance of product design comes from three dimensions; first, functional dimension which related to the performance of primary purpose of the product (Bloch, 2011; Homburg et al., 2015). Second are utilitarian benefits from the product such as safety and convenient. The third dimension is hedonic dimension which means the level of pleasure while using the product (Desmet \& Hekkert, 2007; Bloch, 2011).

More than that, product design can serve many purposes such as; source of information, handling and promoting (Bloch, 2011). Additionally, some scholars pointed out that product design provide certain roles such as categorizing products, reflecting self-image and lifestyle and identifying the right users of the products (Hellström \& Saghir, 2007).

Product design includes essential components; color is one of the most product design factors that can be used to define the products and it's essential for customer interest and selection. Color is core factor for product evaluation and consumers' assessments (Clement, 2007; Singh, 2006). Moreover, the product color has major influence on consumers' behavior, preference and decision making ((Kauppinen-Räisänen, 2014; Labrecque et al., 2013). Recently, many intentions are placed to the effects of color during product design (White-Sax, 2000).

Regarding positioning, color has a significant role to differentiate any product from its competitors. In addition, color can be used as a sign for price or quality, to improve business to increase revenue, and is an important tool for marketers to affect consumers' decisions (Andrews \& Smith, 1996; Beneke et al., 2015; Garber et al., 2000; Singh, 2006). The bottled water package design as a beverage product Chou et al. (2009) founded that black, white, blue or green, were commonly used to reflect its purity and cleanness of the product. Ndubisi \& Funk (2004) point out color can enhance consumers' memory by increasing the recognition of product as color is the fastest factor which, directs attention to product. However, consumers' color preferences differ according to the 
product, age and culture (Bellizzi et al., 1983; Grossman \& Wisenblit, 1999; Kauppinen-Räisänen, 2014; Walsh et al., 1990).

In the case of fast-moving consumer good (FMCG) Kauppinen-Räisänen \& Luomala (2010) illustrated that bottled water is a sold product and the most consumed in the world, thus certain elements should be taking into consideration in the production processes because of the critical consumers' eyes.

H1a: Product design positively influences price fairness.

H1b: Brand trust moderates the relationship between product design and price fairness.

\section{$2.3 E-W O M$}

The concept of Word-of-Mouth (WOM) has been noted for a long time in the marketing research and practice. Researchers have showed that WOM significantly impact consumer choice (e.g., Richins, 1983), post-purchase product perception (e.g., Bone, 1995), and personal selling (e.g., Engel et al., 1969).

E-WOM is interesting since users choose voluntarily to be exposed to commercials/ brands at any given time (Chu \& Kim, 2011). Similar to WOM, research has shown that e-WOM may convey more credible and relevant information than typical marketer information on the web (Gruen et al., 2006). Also, Social media sites (SNS) are built upon user-generated content rather than firm-generated content like other traditional channels (i.e., radio, T.V., newspapers). SNS encompass online information-sharing/ brand with others.

E-WOM on SNS can be defined as "when consumer provide or search for informal product-related advice through the unique applications of these sites" (Chu \& Kim, 2011, p. 50). Consumers sharing information and content generation in SNS is a form of e-WOM (Hennig-Thurau et al., 2004). Companies recently have realized the importance of e-WOM on SNS due to the credibility and relevance of these opinions (Liang \& Scammon, 2011; Gruen et al., 2006; Bickart \& Schindler, 2001). Consumers perceive information and e-WOM coming from their connection and friends on SNS as voluntary opinion (Chu \& Kim, 2011). In recent years, e-WOM on SNS gains power because it empowers consumers over all other powers (i.e., suppliers, competitions, substitutions, and new entry) (Hung \& Li, 2007; King, Racherla, \& Bush, 2014).

H2a: e-WOM positively influences price fairness.

H2b: Brand trust moderates the relationship between e-WOM and price fairness.

\subsection{Brand Trust}

Brand trust is defined as the psychological state in the mind of consumers (Rousseau et al., 1998). Several definitions were found in the literature for brand trust. One of these definitions is the (Grabner- Krauter, 2002) following, they said "trust reduces complexity in situations of uncertainty". Also, trust was defined by (Mayer et al., 1995) as "the willingness of a party to believe the actions of another party based on the expectation that the other will perform a particular action properly, irrespective of the ability to monitor or control the other party." Chaudhuri \& Holbrook (2001) conceptualize the concept of brand trust, showing the impact of brand trust of prices and market share. However, the authors did not test the antecedents of brand trust. Thus, understanding the basis for consumers' value is still unanswered.

Additionally, there is a positive relationship between trust and attitude which enhance the cooperation (Gambetta, 2000; Jarvenpaa et al., 2000; Joubert \& Wishart, 2012; McKnight et al., 2002; Pavlou \& Fygenson, 2006). From another point of view, Bao et al. (2016) found that customer satisfaction has a positive influence on trust in the seller, which plays a major role in increasing the repurchase intention. Brand trust is a critical factor for understanding the marketing relationship, especially when it aligns with commitment (Morgan \& Hunt, 1994). That means brand trust leads consumers to perceive higher value.

Commitment defined as "an enduring desire to maintain a valued relationship" (Moorman, Zaltman, \& Deshpande, 1992, p. 316). In business, trust is mainly the most important element in the transaction processes (Ba, 2001). Generally, studies have pointed out that brand trust has a positive influence on the buying behavior because it reduces the uncertainty level to both seller and buyer (Kenning, 2008). Brand trust may not act as trigger to purchase intention, but it helps consumers to have higher value of the product (Ha \& Perks, 2005).

\subsection{Price Fairness}

Based on behavioral economics, consumers do not take optimal decision but they take the satisficing alternative. The "satisficing alternative" happened when consumers believe maximizing utility comes at high cost, so they settle for less (Simon, 1982). 
Price fairness depends on social and economic factors (Maxwell, 1995). The perception of price fairness may be formulated by word of mouth, product design and brand trust. The price fairness is defined as "a judgment of whether an outcome and/or process to reach an outcome are reasonable, acceptable or just." (Xia, Monroe, \& Cox, 2004, p. 1). The definition indicates that consumers may compare brands prices with norms and other reference prices. Another definition of price fairness is the consumers' judgment of a price as reasonable, just, and legitimate (Campbell, 2007; Haws \& Bearden, 2006).

The price literature shows that there is a balance between brand trust and fair price. If this balance violated, consumers may not trust a brand and/or may perceive prices as unfair. This means that the price and trust should be balanced to increase profit and value for customers (Kahneman, Knetsch, \& Thaler 1986). Consumers are more willing to pay higher prices if they trust the brand, because they feel committed to that brand (Aaker, 1996). That is to say, consumers are prepared to pay higher prices for trusted bands. Price tolerance means that brand A (trusted brand) and brand B (untrusted brand) will have different prices. The price in trusted brand will be higher than in untrusted brand (Krishnmurthi \& Raj, 1991).

Price fairness might not lead to purchase intention which means that when consumer perceive a product to have a fair price they may not directly have intention to purchase the product. Urbany, Madden, \& Dickson (1989) found that price fairness may not directly predict consumers' behavior or intentions. Thus, consumers may consider the prices as fair and do not intention to purchase the product. We hypothesis the following:

H3: Brand trust is positively influences price fairness.

\subsection{Research Model}

This study will be based on the following proposed model

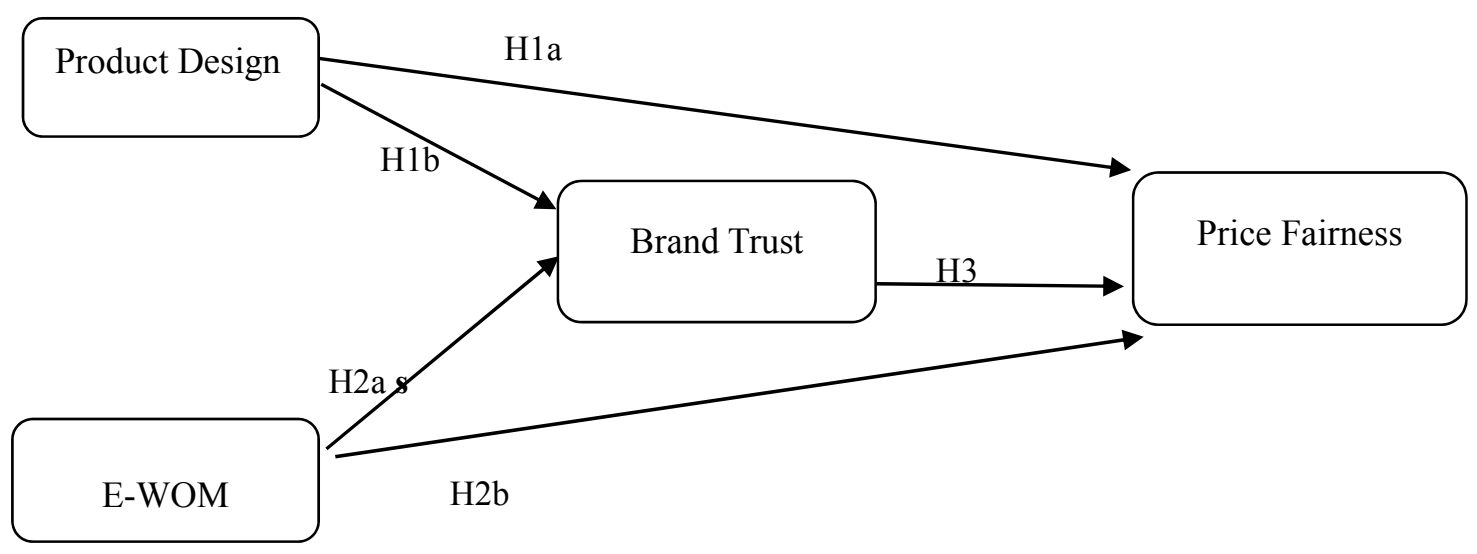

Figure 1. Research model

\subsection{Research Methodology}

We tested the relationships between the constructs using Structural Equation Modeling (SEM) with Maximum Likelihood (ML) estimate. The data was collected using general population in online channels that lives in Saudi Arabia. At the beginning of the survey, we asked the participants a screening questions such as whether they drink bottled water or no. After the screening questions, the participants were asked questions related to the main construct in the survey. In approximately five weeks, a total of 1079 completed and usable responses from the total participants. We tested the non-response bias by comparting the mean for early response and the late ones and we found evidence that non-bias response is not an issue. We found that no single constructs account for more than $66 \%$ of the variance using Harman factor test to control for common method bias (Podsakoff \& Organ, 1986) thus indicating that common method bias is not an issue.

\subsection{Instrument Design}

Most of the constructs in this study were adopted from the literature. For example, E-WOM was measured by four items adopted from Henning-Thurau et al. (2004). Brand Trust scale with four items was adopted from (Lau $\&$ Lee, 1999). Also, we adopted price fairness scale from Bei \& Chiao (2001) and adopted a scale to measure product design with seven items from Winnie \& Ruto (2015). The initial scales were adopted in English, then we translated the scale into Arabic. We used experts' opinion to translate the scale to Arabic. Back translation was 
conducted to ensure consistency. Demographics were asked and added to the questionnaire.

\section{Results}

\subsection{Reliability and Validity of Measures}

As we mentioned above, the scales for the constructs were adopted from the literature. We asked professionals both in English and in marketing discipline to translate and back translation to ensure face validity. Both exploratory factor analysis (EFA) and confirmatory factor analysis (CFA) were conducted to develop the measurement model. EFA extracted 4 factors for this model. Then, we confirmed the result using structural equation modeling (Anderson \& Gerbing, 1988). On average the factor loadings are greater than 0.671 for each construct (for more details refer to the Appendix table 2).

Looking at the global fit indices, we found that the model in this study has acceptable fit between the data and factor structure. All composite reliability values are greater than $\langle 0.761\rangle$, thus ensures the reliability of the measures (Nunnally, 1978). All AVEs are greater than $<0.50>$, thus confirms the convergent validity. As Fornell \& Larcker (1981) recommended that all of the square roots of AVEs are greater than the inter-construct correlations. Moreover, AVEs are greater than the average shared variance (ASV) (Hair et al., 2010), thus further confirming discriminant validity. Please see $<$ table $1>$ for details of the measurement model (for more details refer to the Appendix table 1$)$. The model fit was also appropriate $\left(\mathrm{X}^{2}=354.044 ; \mathrm{df}=144 ; \mathrm{p}\right.$-value $=0.00 ; \mathrm{CFI}=$ 0.98; RMSEA $=0.037$; NFI $=0.96 ; \mathrm{IFI}=0.98 ; \mathrm{RMR}(\mathrm{SRMR})=0.040 ;(0.000) ; \mathrm{GFI}=0.96)$ (Hair, Black, Babin, Anderson, \& Tatham, 2006, p. 667). The global fit indices in table 1 indicate that the model fit is acceptable.

Table 1 . Model validity measures

\begin{tabular}{lllllll}
\hline & CR & AVE & P-Fairness & Design & Trust & EWOM \\
\hline P-Fairness & 0.934 & 0.739 & $\mathbf{0 . 8 6}$ & & & \\
Design & 0.855 & 0.500 & 0.205 & $\mathbf{0 . 7 0 7}$ & & \\
Trust & 0.899 & 0.690 & 0.307 & 0.096 & $\mathbf{0 . 8 3 1}$ & \\
EWOM & 0.783 & 0.506 & 0.038 & 0.113 & 0.116 & $\mathbf{0 . 7 1 2}$ \\
\hline
\end{tabular}

Table 2. (CFA) Confirmatory factor loading

\begin{tabular}{|c|c|c|c|c|}
\hline \multirow[b]{2}{*}{ Items } & \multicolumn{4}{|c|}{ Component } \\
\hline & 1 & 2 & 3 & 4 \\
\hline P1 The prices of bottled water are logical. & 0.912 & & & \\
\hline P2 The prices of bottled water are fair. & 0.901 & & & \\
\hline P3 The prices of bottled water are very reasonable. & 0.891 & & & \\
\hline P4 The prices of bottled water are good deal. & 0.869 & & & \\
\hline P5 The prices of bottled water are acceptable. & 0.800 & & & \\
\hline D1 The more interesting the design/shape of the package the more likely I am to purchase it & & 0.844 & & \\
\hline D2 A package design/shape that is decorative appeals to me. & & 0.789 & & \\
\hline D3 I buy a bottled water because the design of the package is attractive. & & 0.786 & & \\
\hline D4 The more interesting the design/shape of the package the more likely I am to purchase it. & & 0.706 & & \\
\hline D5 I buy a bottled water because the design of the package is familiar to me. & & 0.693 & & \\
\hline D6 The package design/shape is an indicator of the value of the bottled water. & & 0.671 & & \\
\hline T1 I trust this brand bottled water. & & & 0.898 & \\
\hline $\begin{array}{l}\text { T2 I feel secure when I buy this brand of bottled water because I know that it will never let } \\
\text { me down. }\end{array}$ & & & 0.861 & \\
\hline T3 This brand of bottled water offers me a product with a constant quality level. & & & 0.837 & \\
\hline T4 This is an honest brand of bottled water. & & & 0.832 & \\
\hline EWOM1. I always provide my opinion with other members on social media. & & & & 0.897 \\
\hline EWOM2 I always share my experiences with other member on social media. & & & & 0.872 \\
\hline EWOM3. I post links of videos/articles/pictures on social media. & & & & 0.800 \\
\hline EWOM4 Overall, social media is important source of information for me. & & & & 0.397 \\
\hline extracted $(67.979 \%)$ & 26.774 & 16.47 & 13.569 & 11.165 \\
\hline Reliability & 0.933 & 0.853 & 0.898 & 0.761 \\
\hline
\end{tabular}

\subsection{Hypotheses Testing}

We tested the relationships between the constructs using Structural Equation Modeling (SEM), which allow multiple paths to be tested in the same time, Maximum Likelihood (ML) estimate. The path estimate, t-values 
and fit indices are presented in Table 3 and indicate a good fit between the model and the data $\left(X^{2}=433.214\right.$; df $=145 ; \mathrm{p}$-value $=0.00 ; \mathrm{CFI}=0.974 ; \mathrm{RMSEA}=0.44 ; \mathrm{NFI}=0.962 ; \mathrm{IFI}=0.974 ; \mathrm{RMR}(\mathrm{SRMR})=0.075 ;(0.000)$; GFI $=0.958$ ). The global test for the model indicates that the data fit the model, which is evidence by the goodness of fit indicators.

Next, we are testing each individual path, as local test, to determine if our hypotheses are supported or not. Each hypothesis was tested by examining the p-value within the model. The first hypothesis (H1a) that product design influenced price fairness. The path estimate extracted from the Amos model shows that there is a positive relationship between product design and price fairness ( $\mathrm{p}$-value 0.000). That indicates a support to our hypothesis. Second, we hypothesized that e-WOM positively influenced price fairness (H2a). The pat estimate indicates $(-0.016)$ that e-WOM does not influence price fairness directly (p-value 0.615$)$. The third hypothesis suggests that brand trust influenced price fairness positively and the path estimate $(0.291)$ indicates a support to that hypothesis (p-value 0.000) (H3).

The indirect relationships through brand trust between product design and price fairness indicates a supported to our hypothesis $(\mathrm{H} 1 \mathrm{~b})$ with path estimate $(0.0000)$ and p-value $(0.000)$. Our last hypothesis suggests that brand trust mediates the relationships between e-WOM and price fairness $(\mathrm{H} 2 \mathrm{~b})$. The path estimate $(0.0000)$ indicates support to our hypothesis with p-value (0.000).

Table 3. The results of hypotheses

\begin{tabular}{llll}
\hline Hypothesized relationships & Path estimate & p-value & Hypotheses supported \\
\hline H1a: Product Design $\rightarrow$ Price Fairness & $\mathbf{0 . 1 5 8}$ & $\mathbf{0 . 0 0 0}$ & Supported \\
H2a: e-WOM $\rightarrow$ Price Fairness & -0.016 & 0.615 & Not- Supported \\
H3: Brand Trust $\rightarrow$ Price Fairness & $\mathbf{0 . 3 6 5}$ & $\mathbf{0 . 0 0 0}$ & Supported \\
\hline
\end{tabular}

Indirect effect through brand trust

\begin{tabular}{llll}
\hline Relationship & Direct without mediator & Direct with Mediator & Indirect \\
\hline $\mathrm{H} 1 \mathrm{~b}:$ Product Design $\rightarrow$ Brand Trust $\rightarrow$ Price Fairness & $0.176 * * *$ & $0.022^{*}$ & Partial mediation \\
$\mathrm{H} 2 \mathrm{~b}: \mathrm{e}-\mathrm{WOM} \rightarrow$ Brand Trust $\rightarrow$ Price Fairness & $-0.016(\mathrm{~ns})$ & $0.031^{* * *}$ & Full mediation \\
Note. $* * *=\mathrm{p}<0.000, *=\mathrm{p}<0.05, \mathrm{~ns}=$ "not significant". & & &
\end{tabular}

\section{Discussion}

This study attempts to enhance our understanding of price fairness, brand trust, electronic word of mouth (e-WOM), and product design and how these constructs would transfer a product to be differentiable. The results of the study indicate that product design and brand trust have a direct impact on price fairness. Furthermore, brand trust mediates the relationships between product design and price fairness. Moreover, brand trust mediates the relationships between e-WOM and price fairness. However, e-WOM does not have an influence on price fairness.

A possible explanation for the non-significant effect of e-WOM may be because of the relationship between price and word of mouth. There is a reverse relationship between price fairness and word of mouth. A satisfied customer who perceived the prices as fair may spread positive word of mouth. Researchers suggest that specific emotions may arise from price fairness that is more relevant to word of mouth (Bagozzi, Gopinath, \& Nyer, 1999). Consumers may spread negative word of mouth to cope negative feeling of unfair prices. Taken together, these findings have important implications for product that are moving from commodity to brand.

\section{Conclusion}

This study provides insights for marketers to understand the transition between commodity and brand. It also adds to the current literature on price fairness and brand trust by highlighting the impact of product design and e-WOM. Our results confirm the findings in previous research that product design is essential when changing product positioning and product image (Brunner et al., 2016). Also, brand trust may not act as trigger to purchase intention, but it helps consumers to have higher value of the product (Ha \& Perks, 2005). Next, the theoretical and managerial implications to the results of the study are discussed.

\section{Implications}

This study has several theoretical and managerial implications. To start with, this study broadens our understanding of the product transformation from commodity to brand. This study provides insights to managers 
how product design, e-WOM, brand trust and price fairness cloud transfer a product from commodity product into differentiated product that be able to meet the unique needs for consumers better than their competition.

The implications for managers are to help them to differentiate the product and increase brand their brand trust for consumers to perceive the product price. Customers may perceive the prices of a product as fair if the design of the product is differentiable and they trust the brand. Commodity products are homogenous with unrecognized brand. Most products start out as a commodity then it turns into strong brand (Pennington \& Ball, 2009). Our results help manager to transfer their product into strong brands by make differentiated product design, make consumers trust the brand and spread e-WOM. As Levitt (1980) says that "there is no such thing as commodity". Water as the most basic product human need consumer strive for more differentiated product and want to trust the brand. Also, managers should understand price and how consumers perceive prices. Our study gives managers insights into how consumers see prices as unfair by focusing on product design and brand trust.

\section{Limitations and Future Studies}

This study faced some limitations such as; some of the participants did not try the tap water before. The differences between bolted water brands are small which make it difficult to distinguish between them. Also, sometimes the convergence in prices confuses the participants.

Further studies may be conducted to find out relationship between consumers' behavior and the brand names. The purchase decisions of the branded commodity may be explored in detail. A comparison studies could be conducted cross cultures.

\section{Acknowledgment}

The authors extend their appreciation to the Deanship of Scientific Research at King Saud University, for financing the study through the Research Center of College of Business Administration.

\section{References}

Aaker, D. A. (1991). Managing Brand Equity. New York: the Free Press.

Achenbaum, A. (1993). The mismanagement of brand equity. ARF Fifth Annual Advertising and Promotion Workshop.

Alderson, W. (1957). Marketing Behavior and Executive Action: A Functionalist Approach to Marketing. Journal of Farm Economics, 41.

Andrews, J., \& Smith, D. C. (1996). In search of the marketing imagination. Factors affecting the creativity of marketing programs for mature products. Journal of Marketing Research, 33, 174-187. https://doi.org/10.2307/3152145

Azzi, A., Battini, D., Persona, A., \& Sgarbossa, F. (2012). Packaging design: General framework and research agenda. Packaging Technology and Science, 25, 435-456. https://doi.org/10.1002/pts.993

Bagozzi, R. P., Gopinath, M., \& Nyer, P. U. (1999). The role of emotions in marketing. Journal of the Academy of Marketing Science, 27(2), 184. https://doi.org/10.1177/0092070399272005

Bei, L. T., \& Chiao, Y. C. (2001). An integrated model for the effects of perceived product, perceived service quality, and perceived price fairness on consumer satisfaction and loyalty. Journal of Consumer Satisfaction Dissatisfaction and Complaining Behavior, 14, 125.

Bellizzi, J., Crowley, A. E., \& Hasty, R. W. (1983). The effects of color in store design. Journal of Retailing, 59, 21-45.

Beneke, J., Mathews, O., Munthree, T., \& Pillay, K. (2015). The role of package colour in influencing purchase intent of bottled water. Journal of Research in Marketing and Entrepreneurship, 17(2), 165-192. https://doi.org/10.1108/JRME-05-2015-0030

Bloch, P. H. (2011). Product design and marketing: reflections after fifteen years. Journal of Product Innovation Management, 28(3), 378-380. https://doi.org/10.1111/j.1540-5885.2011.00805.x

Bolton, L. W., \& Joseph, W. A. (2003). Consumer Perceptions of Price (Un) Fairness. Journal of Consumer Research, 29(4), 474-491. https://doi.org/10.1086/346244

Bone, P. F. (1995). Word-of-mouth effects on short-term and long-term product judgments. Journal of Business Research, 32, 213-223. https://doi.org/10.1016/0148-2963(94)00047-I

Bottled Water Market. (n. d.) International Bottled Water Association. Retrieved from http://www.bottledwater.org/economics/bottled-water-market 
Brunner, C. B., Ullrich, S., Jungen, P., \& Esch, F. (2016). Impact of symbolic product design on brand evaluations. Journal of Product \& Brand Management, 25(3), 307-320. https://doi.org/10.1108/JPBM-06-2015-0896

Campbell, M. C. (2007). Says Who?!' How the Source of Price Information and Affect Influence Perceived Price (Un) Fairness. Journal of Marketing Research, 44, 261-271. https://doi.org/10.1509/jmkr.44.2.261

Chou, M. C., Chiu, P. H. \& Wang, R. W. Y. (2009). Employment of visual elements for identifying beverage package design discrepancies. International Association of Societies of Design Research.

Clement, J. (2007). Visual influence on in-store buying decision: an eye-track experiment on the visual influence of packaging design. Journal of Marketing and Management, 23(9/10), 917-928. https://doi.org/10.1362/026725707X250395

Desmet, P., \& Hekkert, P. (2007). Framework of product experience. International Journal of Design, 1(1). Retrieved from www.ijdesign.org/ojs/index.php/IJDesign/article/view/66/15

Doria, M. D. (2006). Bottled water versus tap water: understanding consumers-preferences. $J$ Water Health, 271-276.

Dumlupinar, B. (2006). Market commoditization of products and services. Review of Social, Economic \& Business Studies, 9(10), 101-114.

Engel, J. E., Blackwell, R. D., \& Kegerreis, R. J. (1969). How information is used to adopt an innovation. Journal of Adverting Research, 9, 3-8.

Feliciano, J. (2014). Bottled water in 2014: packaging, branding, and the search for value. Retrieved from http://blog.euromonitor.com/2014/02/bottled-water-in-packagingbranding-

Ferrier, C. (2001). Bottled water: understanding a social phenomenon. AMBIO: A Journal of the Human Environment, 30(2), 118-119. https://doi.org/10.1579/0044-7447-30.2.118

Franzen, G. (1999). Brands and Advertising: How Advertising Effectiveness Influences Brand Equity. Oxfordshire: Admap Publications.

Garber, L. L., Jr. Burke, R. R., \& Jones, J. M. (2000). The Role of Package Appearance in Consumer Purchase Consideration and Choice. Marketing Science Institute Working Paper Series, Boston, MA.

Grossman, P. R., \& Wisenblit, Z. J. (1999). What we know about consumers' color choices. Journal of Marketing Practice: Applied Marketing Science, 5(3), 78-88. https://doi.org/10.1108/EUM0000000004565

Gruen, T. W., Osmonbekov, T., \& Czaplewski, A. J. (2006). eWOM: The impact of customer-to-customer online know-how exchange on customer value and loyalty. Journal of Business Research, 59(4), 449-456. https://doi.org/10.1016/j.jbusres.2005.10.004

Ha, H. Y., \& Perks, H. (2005). Effects of consumer perceptions of brand experience on the web: Brand familiarity, satisfaction and brand trust. Journal of Consumer Behaviour, 4(6), 438-452. https://doi.org/10.1002/cb.29

Haws, K. L., \& Bearden, W. O. (2006). Dynamic Pricing and Consumer Fairness Perceptions. Journal of Consumer Research, 33(3), 304-311. https://doi.org/10.1086/508435

Hellström, D., \& Saghir, M. (2007). Packaging and logistics interactions in retail supply chain. Packaging Technology and Science, 20, 197-216. https://doi.org/10.1002/pts.754

Homburg, C., Schwemmle, M., \& Kuehnl, C. (2015). New product design: concept, measurement, and consequences. Journal of Marketing, 79(3), 41-56. https://doi.org/10.1509/jm.14.0199

IBWA. (n. d.). How Much Does Bottled Water Cost?

Jaffee, D., \& Newman, S. (2013). A more perfect commodity: bottled water, global accumulation, and local contestation. Rural Sociology, 78(1), 1-28. https://doi.org/10.1111/j.1549-0831.2012.00095.x

Johnson, M. D., Gustafsson, A., Andreassen, T. W., Lervik, L., \& Cha, J. (2001). The evolution and future of national customer satisfaction index models. Journal of Economic Psychology, 22(2), 217-245. https://doi.org/10.1016/S0167-4870(01)00030-7

Kahneman, D., Jack, L. K., \& Richard, T. (1986). Fairness and the Assumptions of Economics. Journal of Business, 59(4), S285-S300. https://doi.org/10.1086/296367 
Kauppinen-Räisänen, H. (2014). Strategic use of colour in brand packaging. Packaging Technology and Science, 27, 663-676. https://doi.org/10.1002/pts.2061

Kauppinen-Räisänen, H., \& Luomala, H. T. (2010). Exploring consumers' product specific colour meanings. Qualitative Market Research: An International Journal, 13(3), 287-308. https://doi.org/10.1108/13522751011053644

Labrecque, L., Patrick, V. M., \& Milne, G. R. (2013). The marketers' prismatic palette: A review of color research and future directions. Psychology \& Marketing, 30(2), 187-202. https://doi.org/10.1002/mar.20597

Lange, C., Rousseau, F., \& Issanchou, S. (1998). Expectation, liking and purchase behaviour under economical constraint. Food Quality and Preference, 10(1), 31-39. https://doi.org/10.1016/S0950-3293(98)00035-4

Laxer, G., \& Soron, D. (2006). Not for sale: Decommodifying public life. Toronto: University of Toronto Press.

Levitt, T. (1980). Marketing success through differentiation—of anything. Harvard Business Review, 58(1), 83-91.

Ndubisi, N. O., \& Funk, D. (2004). The moderation effect of gender in the relationship between color dimensions and car choice. AIMS Conference Proceeding, India, 28-31, 466-473.

Noble, N., Paul, L., Mcminimee, C., Mallett, M., \& Singh, J. (2009). Packaging trends for bottled water. Journal of Applied Packaging Research, 3(3), 123-136.

Park, C. W., Milberg, S., \& Lawson, R. (1991). Evaluation of brand extensions: The role of product feature similarity and brand concept consistency. The Journal of Consumer Research, 18(2), 185-193. https://doi.org/10.1086/209251

Passport. (2017). Bottled water in Saudi Arabia (pp. 1-7, Rep.). Euromonitor International.

Pennington, J. R., \& Ball, A. D. (2009). Customer branding of commodity products: The customer-developed brand. Journal of Brand Management, 16(7), 455-467. https://doi.org/10.1057/palgrave.bm.2550131

Reuters. (2017). Americans Are Now Drinking More Bottled Water than Soda. Retrieved from http://fortune.com/2017/03/10/soda-tax-bottled-water-americans/

Richins, M. L. (1983). Negative word-of-mouth by dissatisfied consumers: a pilot study. Journal of Marketing, 47, 68-78. https://doi.org/10.2307/3203428

Simms, C., \& Trott, P. (2014). Conceptualizing the management of packaging within new product development: A grounded investigation in the UK fast moving consumer goods industry. European Journal of Marketing, 48(11), 2009-2032. https://doi.org/10.1108/EJM-12-2012-0733

Simon, H. A. (1982). Models of bounded rationality: Empirically grounded economic reason. Journal of Macroeconomics, 2, 425. Cambridge: MIT press.

Singh, S. (2006). Current research development: Impact of color on marketing. Management Decision, 44(6), 783-789. https://doi.org/10.1108/00251740610673332

Urbany, J. E., Madden, T. J., \& Dickson, P. R. (1989). All's not fair in pricing: an initial look at the dual entitlement principle. Marketing Letters, 1(1), 17-25. https://doi.org/10.1007/BF00436145

Walsh, L. M., Toma, R. B., Tuveson, R. V., \& Sondhi, L. (1990). Color preference and food choice among children. Journal of Psychology, 124, 645-653. https://doi.org/10.1080/00223980.1990.10543258

White-Sax, B. (2000). Color complex sophisticated color choices for a diverse market. Drug Store News.

Xia, L., Monroe, K. B., \& Cox, J. L. (2004). The price is unfair! A conceptual framework of price fairness perceptions. Journal of Marketing, 68(4), 1-15. https://doi.org/10.1509/jmkg.68.4.1.42733

\section{Copyrights}

Copyright for this article is retained by the author(s), with first publication rights granted to the journal.

This is an open-access article distributed under the terms and conditions of the Creative Commons Attribution license (http://creativecommons.org/licenses/by/4.0/). 